\title{
Research on the Correlation Between Real Earnings Management, Executive Compensation and Cost Stickiness
}

\author{
Mengjie Yang \\ School of Business, Xi'an International Studies University, Xi'an, Shaanxi, China \\ yangmengj@foxmail.com
}

\begin{abstract}
Based on the data of Chinese A-share listed manufacturing companies from 2018 to 2020, this paper systematically explores the influence mechanism of executive compensation incentive on the relationship between real earnings management and expense stickiness. The empirical results show that:(1) Chinese manufacturing enterprises' real earnings management level is negatively correlated with cost stickiness;(2) Executive compensation is negatively correlated with cost stickiness;(3) Executive compen sation of listed companies is negatively correlated with real earnings management;(4) With the increase of executive compensation, the negative correlation between real earnings management level and expense stickiness weakens.
\end{abstract}

Keywords: Real earnings management, Executive compensation, Cost stickiness, Manufacturing listed company.

\section{Introduction}

Earnings management behavior refers to the behavior of corporate managers to select, control or adjust accounting data by using different accounting policies or actual business activities, with the purpose of improving their own interests and the company's market value[1]. With the continuous development of social economy and productivity, the scale of enterprises has been expanding and the internal division of labor has been refined. In order to meet the needs of specialized production, earnings management not only promotes the healthy development of enterprises, but also causes the separation of ownership and management rights inside enterprises, which further leads to the conflict of interests between the two rights. Executive compensation is an effective incentive to eliminate the conflict of interest and reduce executive agency behavior. When executives make business decisions, if profits decline rapidly, managers tend to take unfair earnings management measures to reduce costs and cover up self-interested behaviors in order to avoid paying fines and damaging reputations, thus resulting in cost stickiness.

In 1985, Healy first proposed the research hypothesis of the relationship between executive compensation and earnings management, and he clearly pointed out that managers have the motivation to adjust manipulative accruals in order to obtain high salaries. For more than 30 years, scholars at home and abroad have been studying earnings management, including earnings management and loss avoidance, earnings management and profit growth, earnings management and IPO, etc. At the same time, domestic scholars have also studied the relationship between earnings management and executive compensation. Fu Qi and Deng Chuan et al.[2-4] found that executive compensation can effectively restrain earnings management behavior of enterprises. However, the existing theoretical research on the relationship between executive compensation and earnings management has not reached a consensus.

At present, Western scholars usually use the "agency problem" to explain the relationship between executive compensation and cost stickiness, believing that corporate executives are self-interested and risk-averse, and will adjust costs and expenses by taking advantage of resources within their control in order to improve their own compensation. Chinese scholars tend to use "principal-agent problem" to explain the reason of cost stickiness. Xie Huobao and Hui Lili (2014) provide empirical evidence for the phenomenon of cost stickiness caused by "agency view". However, the current research on the relationship between executive compensation and cost stickiness is not enough. In the existing literature, Liang Shangkun studied the influence of ownership concentration on cost and expense stickiness of listed companies[5], and Luo Hong et al. (2015) studied the relationship between executive compensation incentive and cost stickiness.

Based on the above analysis, this paper mainly focuses on the following four issues: First, how does real earnings management affect expense stickiness; Second, how the executive compensation of listed companies affects the stickiness of corporate expenses; Thirdly, as the direct controller of real information of listed companies, whether there is a linkage between executive compensation and earnings management behavior; Fourth, what is the impact of executive compensation on the linkage between earnings management and expense stickiness?

The contributions of this paper are as follows: First, it theoretically enriched the existing literature on the correlation between earnings management, executive compensation and expense stickiness, and provided reference for theoretical research in related fields; Second, it can help guide corporate shareholders to pay attention to the correlation between earnings management, executive compensation and expense stickiness, and encourage shareholders to effectively manage costs and expenses by designing reasonable executive compensation system and strengthen corporate internal control; Third, promote the combination of theory and practice, in a better understanding of managers' decisionmaking behavior based on scientific decision-making. 


\section{The Theoretical Analysis and Research Hypothesis}

\subsection{Principal-agent Theory}

The modern principal-agent theory was first proposed by The American economists Berle and Means. After years of research by scholars at home and abroad, principal-agent relationship can be summarized as "through signing explicit or implicit contracts, the principal bearing the risk appoints or hires other agents to provide services to him, and pays appropriate fees according to the validity of the decisions made by the agent and the quantity and quality of the services provided". In accounting, it refers to the separation of enterprise ownership and management rights, resulting in the inconsistency of goals, uncertainty and information asymmetry between subjects exercising the two kinds of power.

\subsubsection{Optimal compensation contract theory}

Optimal compensation contract refers to the close connection between executive compensation and company performance, so as to coordinate business disputes, conflicts of interest, solve agency problems between enterprise managers and owners, and provide incentives for managers. Holmostrom (1979) proposed that when the shareholders of a company can detect the behavior of managers, shareholders should reserve certain salaries for managers. However, this premise is difficult to realize in real life. Therefore, the selection of incentive mode and performance evaluation index must be considered when formulating the optimal compensation incentive contract.

\subsection{Research Hypothesis}

\subsubsection{Real earnings management and expense stickiness}

Management's behavior of real earnings management may either strengthen or weaken cost stickiness. On the one hand, in order to avoid conflicts of interest with shareholders and maintain and improve their own compensation and welfare, managers have both the motivation and ability to avoid losses or even reach profitability through positive earnings management when the enterprise's revenue declines. In this case, the enterprise's expense stickiness is weakened[6]. In other words, enterprise managers tend to control the increase of cost stickiness through positive earnings management, and cost stickiness is negatively correlated with earnings management.

On the other hand, due to China's current legal system is not perfect, the agency problem is serious, earnings management has become a common way for the management of listed companies to achieve their own goals. The internal governance mechanism of an enterprise can reduce the negative moderating effect of real earnings management on expense stickiness[7]. Therefore, this paper puts forward the following conclusions:

H1a: There is a significant positive correlation between real earnings management and expense stickiness.
H1b: There is a significant negative correlation between real earnings management and cost stickiness.

\subsubsection{Executive compensation level and cost stickiness of} listed companies

Anderson et al. (2003) first proposed the concept of cost stickiness and proposed the conjecture that "principal-agent problem leads to cost stickiness". Because it is difficult for enterprise owners to accurately observe the actual work of managers and control their behaviors, managers sometimes determine the amount of expenditure needed for daily operation of enterprises and make operational decisions in order to maximize their own interests (Jensen et al and Meckling, 1976[8]). The influence of executive compensation incentive on management agency problem has been widely confirmed.

On the other hand, the optimal contract theory believes that a reasonable executive compensation contract can effectively motivate the correct behavior of the management, thus reducing the motivation of the management to pursue their own interests (Kanniainen, 2000[9]), effectively reducing agency costs and motivating managers to control costs, thus alleviating cost stickiness.

Based on the above analysis, this paper proposes the following hypotheses:

$\mathrm{H} 2$ : Executive compensation level of listed companies is significantly negatively correlated with cost stickiness.

\subsubsection{Executive compensation and real earnings management of listed companies}

Principal-agent theory shows that there is a certain degree of information asymmetry between shareholders and management because of the separation of management rights and ownership. This theory reveals that the organizational form of modern enterprises contains potential risks, that is, managers, as rational economic people, can exercise a certain degree of discretion in the disclosure of corporate performance indicators (especially accruals) to maximize personal interests[10]. One way to solve the principal-agent problem is to establish an incentive mechanism for executive compensation, so as to realize the convergence of executives' personal interests and shareholders' interests and give play to the synergistic effect between interests. However, in fact, this incentive structure may encourage executives to carry out earnings management in order to maximize their own compensation.

The influence mechanism of executive compensation incentive and earnings management behavior has been confirmed by foreign researches. Steven Balsam (1998), Watts (1986), Ferdinand AIGul et al. (2003) pointed out that in order to maximize bonuses and remuneration, corporate executives, under other conditions being the same, would consider the amount of cash flow and non-manipulative surplus at the end of the year. Select accrual earnings manipulation tools that are beneficial to increase earnings return. Some foreign scholars have found that due to the incentive of short-term compensation contracts, corporate 
executives will adopt earnings management behavior[11-15]. Domestic studies have also reached similar conclusions. For example, Wang Kemin and Wang Zhichao (2007) concluded that there is a significant positive correlation between executive annual salary and earnings management behavior after studying a total of 1,1414 listed companies in Shanghai and Shenzhen stock markets from 2001 to 2004[16]. Li Yanxi (2007) used Dechow model to analyze accrued items of companies in the same industry and found that the motivation of earnings management increased with the increase of executive compensation level. Based on this, this paper proposes the following research hypotheses:

H3a: Executive compensation level of listed companies is positively correlated with real earnings management level.

In recent years, the degree of standardization of the external environment of enterprises has been constantly improving. For the consideration of occupational safety and personal reputation, senior executives gradually realize that the behavior of manipulating accounting profits through earnings management will lose more than gain, and they are more inclined to avoid risks and obtain relatively stable salary. At the same time, in order to better play the supervisory role of performance compensation incentive mechanism on corporate governance, the owners of enterprises improve the supervision of managers' management behavior; Earnings management by corporate executives costs a lot.

Liu Bin et al. (2003) found that Chief Executive Officers (CEOs) do not conduct earnings management in order to improve the salary level. Wei Guoqiang (2009) used Jones model of modified cross section to calculate and found that earnings management behavior significantly decreased after the introduction of compensation incentive mechanism with accounting performance as evaluation standard. Therefore, this paper proposes the following hypotheses:

H3b: The executive compensation level of listed companies is negatively correlated with the real earnings management level.

2.2.4 Executive compensation, real earnings management and fee stickiness

With the increasing stability of executive compensation, they will choose to give up earnings management in order to avoid risks. At the same time, the reduction of real earnings management level will weaken the enterprise's control over the rising cost. Based on this, the following hypotheses are proposed in this paper:

H4: The higher the executive compensation, the weaker the negative correlation between earnings management and expense stickiness.

\section{Research Design}

\subsection{Sample Selection and Data Sources}

This paper selects the data of China's a-share listed manufacturing companies from 2018 to 2020 as research samples and conducts the following screening :(1) excluding listed companies in the financial insurance industry; (2) Sample data with incomplete, missing and outliers were eliminated; (3) Exclude companies with zero executive compensation or fewer than three executives.

After the screening of the above steps, a total of 378 listed companies in a total of 3 years of effective observation data were obtained. In order to ensure the reliability of the results, all continuous variables were treated with $1 \%$ and $99 \%$ tail reduction. All sample data in this study are from CSMAR database; The data processing software and statistical analysis software used in this paper is SPSS 25.0.

\subsection{Definition of Variables}

\subsubsection{Explained variables}

(a) The rate of change of marketing management fees $(\Delta \mathrm{LnEXP})_{\mathrm{t}}$

In this paper, cost stickiness variable is defined as enterprise sales and administrative expenses, and explained variable is defined as the change rate of sales and administrative expenses, that is, the natural logarithm of the ratio of sales and administrative expenses in period $t$ to sales and administrative expenses in period $\mathrm{t}-1$.

(b) Real earnings management level $\left(\operatorname{REM}_{t}\right)$

Real earnings management level (REM) is the explained variable when studying the relationship between executive compensation and real earnings management level. When estimating the real earnings management degree of enterprises, this paper refers to The research ideas of Roychowdhury[17] and the specific estimation model is as follows:

$$
\begin{aligned}
& \frac{C F O_{t}}{\mathrm{At}-1}=\beta_{0}+\beta_{1}\left(\frac{1}{A_{t-1}}\right)+\beta_{2}\left(\frac{R E V_{t}}{A_{t-1}}\right)+\beta_{3}\left(\frac{\Delta R E V_{t}}{A_{t-1}}\right)+\varepsilon_{t} \\
& \frac{P R O D_{t}}{\mathrm{At}-1}=\beta_{0}+\beta_{1}\left(\frac{1}{A_{t-1}}\right)+\beta_{2}\left(\frac{R E V_{t}}{A_{t-1}}\right)+\beta_{3}\left(\frac{\Delta R E V_{t}}{A_{t-1}}\right) \\
& +\beta_{4}\left(\frac{\Delta R E V_{t-1}}{A_{t-1}}\right)+\varepsilon_{t} \\
& \frac{D I S E X P_{t}}{\mathrm{At}-1}=\beta_{0}+\beta_{1}\left(\frac{1}{A_{t-1}}\right)+\beta_{2}\left(\frac{\Delta R E V_{t-1}}{A_{t-1}}\right)+\varepsilon_{t}
\end{aligned}
$$

Where, $C F O_{t}, P R O D_{t}$ and $D I S E X P_{\mathrm{t}}$, respectively represent the cash flow level of operating activities, production cost and controllable expense of enterprise $i$ in year $t$, where production cost is the sum of current operating cost and inventory change, and controllable expense is the sum of current selling expense and management expense; $A_{t-1}$ represents the total ending assets of the ith enterprise in $\mathrm{t}-1 ; R E V_{t}$ represents the operating income of the ith enterprise in year $\mathrm{t} ; \triangle R E V_{t}$ represents the change in the operating income of the ith enterprise in year $\mathrm{t}$.

The behavior of real earnings management will lead to higher abnormal production costs $(A b P R O D)_{t}$, lower abnormal 
operating cash purification $(A b C F O)$, and controllable expenses $(\text { AbDISEXP })_{t}$. Therefore, this paper defines the degree of real earnings management $R E M_{t}$ as:

$$
\text { REM }_{t}=A b P R O D_{t}-A b C F O_{t}-A b D I S E X P_{t}
$$

\subsubsection{Explanatory variables}

(a) Change rate of operating income $(\Delta \mathrm{LnREV})_{\mathrm{t}}$

It's the natural $\log$ of the ratio of revenue in year $t$ to revenue in year $\mathrm{t}-1$.

(b) Real earnings management level $\left(\mathrm{REM}_{\mathrm{t}}\right)$

Real earnings management level $\left(\operatorname{REM}_{t}\right)$ is the explanatory variable when studying the relationship between real earnings management level and expense stickiness, and the relationship between executive compensation, real earnings management level and expense stickiness.

(c) Salary incentive (PAY)

That's the natural $\log$ of the total compensation of the top three executives.

\subsubsection{Control variables}

(a) Income Decline Indicators(DEC)

When the company's operating revenue decreases from the previous year, the value is 1 . If you do the opposite, you take 0.

(b) Company Scale(SIZE)

In terms of the natural log of the company's total assets.

(c) Persistent Indicators of Income Decline $\left(\mathrm{DEC}_{\mathrm{t}-1}\right)$

When the operating income in year $t$ decreases compared with that in year $\mathrm{t}-1$ and the operating income in year $\mathrm{t}-1$ decreases compared with that in year $\mathrm{t}-2$, the value is 1 ; If you do the opposite, you take 0 .

(d) Capital Intensity (AI)

It is the ratio of total assets to operating income.

(e) Human Capital Intensity (EI)

That is, the ratio of total employee compensation and operating income in those days.

To sum up, the names and definitions of variables studied in this paper are shown in Table 1.

Table 1: Variable Definition Table

\begin{tabular}{|c|c|c|c|}
\hline Variable Type & Variable Name & Variable Symbol & Variable Definition \\
\hline \multirow{2}{*}{$\begin{array}{l}\text { Explained } \\
\text { Variables }\end{array}$} & $\begin{array}{l}\text { The rate of change of marketing } \\
\text { management fees }\end{array}$ & $(\Delta \mathrm{LnEXP})_{\mathrm{t}}$ & $\begin{array}{c}\text { The natural logarithm of the ratio of sales and administrative expenses in period t } \\
\text { to sales and administrative expenses in period t-1 }\end{array}$ \\
\hline & Real earnings management level & $\mathrm{REM}_{\mathrm{t}}$ & $R E M_{t}=A b P R O D_{t}-A b C F O_{t}-A b D I S E X P_{t}$ \\
\hline \multirow{3}{*}{$\begin{array}{l}\text { Explanatory } \\
\text { Variables }\end{array}$} & Change rate of operating income & $(\Delta \mathrm{LnREV})_{\mathrm{t}}$ & the natural $\log$ of the ratio of revenue in year $t$ to revenue in year $t-1$ \\
\hline & Real earnings management level & $\mathrm{REM}_{\mathrm{t}}$ & $R E M_{t}=A b P R O D_{t}-A b C F O_{t}-A b D I S E X P_{t}$ \\
\hline & Salary incentive & PAY & the natural log of the total compensation of the top three executives \\
\hline \multirow{5}{*}{$\begin{array}{l}\text { Control } \\
\text { Variables }\end{array}$} & Income Decline Indicators & DEC & $\begin{array}{l}\text { When the company's operating revenue decreases from the previous year, the } \\
\text { value is } 1\end{array}$ \\
\hline & Company Scale & SIZE & the natural log of the company's total assets \\
\hline & $\begin{array}{l}\text { Persistent Indicators of Income } \\
\text { Decline }\end{array}$ & $\mathrm{DEC}_{\mathrm{t}-1}$ & $\begin{array}{l}\text { When the operating income in year t decreases compared with that in year } \mathrm{t}-1 \text { and } \\
\text { the operating income in year } \mathrm{t}-1 \text { decreases compared with that in year } \mathrm{t}-2 \text {, the } \\
\text { value is } 1\end{array}$ \\
\hline & Capital Intensity & AI & the ratio of total assets to operating income \\
\hline & Human Capital Intensity & EI & the ratio of total employee compensation and operating income in those days \\
\hline
\end{tabular}

\subsection{Model Construction}

3.3.1 The impact of real earnings management on cost stickiness

In order to investigate the impact of real earnings management on cost stickiness, this paper uses multiple regression analysis model and adds real earnings management as an explanatory variable to the model.

Model 1: $(\Delta \mathrm{LnEXP})_{\mathrm{t}}=\beta_{0}+\beta_{1} \times \mathrm{REM}_{\mathrm{t}}+\beta_{2} \times(\Delta \mathrm{LnREV})_{\mathrm{t}}+$ $\beta_{3} \times \mathrm{DEC}+\beta_{4} \times \mathrm{SIZE}+\beta_{5} \times \mathrm{AI}+\beta_{6} \times \mathrm{EI}+\varepsilon$

In model $1, \beta_{1}$ shows the influence of real earnings management on cost stickiness. When the operating revenue increases by $1 \%$, the sales management expense increases by $\beta_{2} \%$. If $\beta_{1}<0$, it indicates that real earnings management is negatively correlated with cost stickiness. On the contrary, there is a positive correlation.

\subsubsection{The impact of executive compensation on cost stickiness}

In order to investigate the impact of executive compensation on cost stickiness, this paper uses multiple regression analysis model and adds executive compensation as an explanatory variable into the model.

Model 2: $(\Delta \mathrm{LnEXP})_{\mathrm{t}}=\alpha_{0}+\alpha_{1} \times(\Delta \mathrm{LnREV})_{\mathrm{t}}+\alpha_{2} \times \mathrm{PAY}+$ $\alpha_{3} \times \mathrm{DEC}+\alpha_{4} \times \mathrm{SIZE}+\alpha_{5} \times \mathrm{AI}+\alpha_{6} \times \mathrm{EI}+\varepsilon$ 
In model $2, \alpha_{2}$ shows the impact of executive compensation on cost stickiness. When the operating revenue increases by $1 \%$, the sales and management expense increases by $\alpha_{1} \%$. If $<0$, it indicates that cost stickiness will decrease with the increase of salary level, that is, real earnings management is negatively correlated with cost stickiness. On the contrary, there is a positive correlation.

3.3.3 The relationship between executive compensation and real earnings management level

In order to investigate the relationship between executive compensation and real earnings management, a regression model is constructed.

Model 3: $\mathrm{REM}_{\mathrm{t}}=\gamma_{0}+\gamma_{1} \times \mathrm{PAY}+\gamma_{2} \times \mathrm{SIZE}+\gamma_{3} \times \mathrm{DEC}_{\mathrm{t}-1}+$ $\gamma_{4} \times \mathrm{AI}+\gamma_{5} \times \mathrm{EI}+\varepsilon$

In the model, $\gamma_{1}$ represents the impact of executive compensation on the real earnings management level. $\gamma_{1}<0$ means that the executive compensation is inversely related to the real earnings management level, while $\gamma_{1}>0$ means that the executive compensation is directly proportional to the real earnings management level.

3.3.4 The relationship among executive compensation, real earnings management and fee stickiness

In order to study the relationship among executive compensation, real earnings management and expense stickiness, this paper constructs a regression model.

Model 4: $(\Delta \mathrm{LnEXP})_{\mathrm{t}}=\delta_{0}+\delta_{1} \times \mathrm{REM}_{\mathrm{t}}+\delta_{2} \times(\Delta \mathrm{LnREV})_{\mathrm{t}}+$ $\delta_{3} \times \mathrm{PAY}+\delta_{4} \times \mathrm{SIZE}+\delta_{5} \times \mathrm{DEC}_{\mathrm{t}-1}+\delta_{6} \times \mathrm{AI}+\delta_{7} \times \mathrm{EI}+\varepsilon$
With the involvement of executive compensation, the correlation coefficient between real earnings management level and fee stickiness is $\delta_{1}$, if $\delta_{1}<\beta_{1}$, it indicates that the negative correlation between real earnings management level and fee stickiness will weaken with the increase of executive compensation.

\section{Analysis of Empirical Results}

\subsection{Descriptive Statistical Analysis}

Table 2 lists the statistical results of major variables in the model with a time span of 2 years. Among them, the maximum value and minimum value of change rate of management expense are 0.6526 and -1.1201 respectively, and the mean value and standard deviation are -0.0973 and 0.2683 respectively, indicating that there are differences in operation of companies of different sizes and at different stages of development. The standard deviation of real earnings management is 1.2068 , indicating that the degree of real earnings management behavior varies greatly among different companies. The standard deviation of the variation rate of operating income is 0.3487 , which is larger in general than the standard deviation of marketing and management expenses, proving that the sample companies have cost stickiness. The standard deviation of capital intensity is 5.6517 , indicating that capital intensity varies greatly among different companies. The standard deviation of human capital intensity is 0.1848 , which shows that the difference of human capital intensity of sample companies is relatively small. The sample of companies whose revenues declined from 2012 to 2020 compared with the previous year accounted for 53\%; the sample of companies with declining revenue for two consecutive years accounted for 23.6 percent.

Table 2: Descriptive Statistics of Major Variables

\begin{tabular}{|c|c|c|c|c|c|c|}
\hline Variable Name & $\begin{array}{c}\text { Variable } \\
\text { Symbol }\end{array}$ & $\begin{array}{c}\text { Observation } \\
\text { Number }\end{array}$ & Maximum & Minimum & Average & $\begin{array}{c}\text { Standard } \\
\text { Deviation }\end{array}$ \\
\hline $\begin{array}{c}\text { The rate of change of marketing } \\
\text { management fees }\end{array}$ & $(\Delta \mathrm{LnEXP})_{\mathrm{t}}$ & 1134 & 0.6526 & -1.1201 & -0.0973 & 0.2683 \\
\hline Real earnings management level & $\mathrm{REM}_{\mathrm{t}}$ & 1134 & 6.9270 & -5.5069 & 0.0028 & 1.2068 \\
\hline Change rate of operating income & $(\Delta \mathrm{LnREV})_{\mathrm{t}}$ & 1134 & 1.6666 & -1.3090 & -0.0276 & 0.3487 \\
\hline Salary incentive & $\mathrm{PAY}$ & 1134 & 7.9635 & 3.5979 & 5.3906 & 0.6826 \\
\hline Income Decline Indicators & $\mathrm{DEC}$ & 1134 & 1 & 0 & 0.5281 & 0.5006 \\
\hline Company Scale & $\mathrm{SIZE}$ & 1134 & 26.6104 & 19.8141 & 26.1997 & 1.2239 \\
\hline Persistent Indicators of Income Decline & $\mathrm{DEC}$ & 1134 & 1 & 0 & 0.2303 & 0.4222 \\
\hline Capital Intensity & $\mathrm{AI}$ & 1134 & 62.4417 & 0.4563 & 3.0781 & 5.6517 \\
\hline Human Capital Intensity & EI & 1134 & 2.4646 & 0.00002 & 0.0353 & 0.1848 \\
\hline
\end{tabular}

\subsection{Correlation Analysis}

See Table 3 for correlation test results of major variables, including Pearson correlation coefficient and significance level. It can be seen that the change rate of sales management expense is negatively correlated with the real earnings management level, and it is significant at the level of $1 \%$, which provides preliminary support for the correctness of hypothesis 1B. Executive compensation is positively correlated with the level of real earnings management, which provides preliminary support for the correctness of hypothesis 3a. In addition, it can be seen from the correlation coefficients among variables listed in Table 3 that the absolute value of the correlation coefficients between most independent variables is less than 0.700 , indicating that there is no significant multicollinearity among the control variables in this paper, and its selection is effective. 
Table 3: Correlation Analysis of Main Variables

\begin{tabular}{|c|c|c|c|c|c|c|c|c|c|}
\hline & $(\Delta \operatorname{LnEXP})_{\mathrm{t}}$ & $\mathrm{REM}_{\mathrm{t}}$ & $(\Delta \mathrm{LnREV})_{\mathrm{t}}$ & PAY & DEC & SIZE & $\mathrm{DEC}_{\mathrm{t}-1}$ & AI & EI \\
\hline$(\Delta \operatorname{LnEXP})_{t}$ & 1 & & & & & & & & \\
\hline $\mathrm{REM}_{\mathrm{t}}$ & $-0.282 * *$ & 1 & & & & & & & \\
\hline$(\Delta \mathrm{LnREV})_{\mathrm{t}}$ & $0.348^{* *}$ & $-0.273^{* *}$ & 1 & & & & & & \\
\hline PAY & 0.045 & 0.020 & 0.146 & 1 & & & & & \\
\hline DEC & $-0.249 * *$ & $0.155^{*}$ & $-0.665^{* *}$ & -0.095 & 1 & & & & \\
\hline SIZE & -0.019 & $-0.299 * *$ & 0.080 & 0.476 ** & $-0.179^{*}$ & 1 & & & \\
\hline $\mathrm{DEC}_{\mathrm{t}-1}$ & 0.105 & 0.035 & 0.072 & 0.016 & -0.058 & -0.060 & 1 & & \\
\hline AI & 0.055 & $0.168^{*}$ & -0.033 & -0.056 & -0.011 & -0.071 & $0.283^{* *}$ & 1 & \\
\hline EI & 0.050 & 0.141 & -0.088 & -0.058 & 0.072 & -0.119 & 0.132 & 0.817 *** & 1 \\
\hline
\end{tabular}

Note: $* *$ represents significant correlation at $1 \%$ level; * indicates a significant correlation at the $5 \%$ level.

\subsection{Fundamental Regression Analysis}

4.3.1 The impact of real earnings management on cost stickiness.

Table 4 shows the regression analysis results of Model 1. As can be seen from the results, the adjustment $\mathrm{R}^{2}$ of the regression model is 0.155 , and it is significant at the $1 \%$ level, indicating that the model has a good goodness of fit. The regression coefficient between the real earnings management level and cost stickiness is negative, indicating that the real earnings management level is negatively correlated with cost stickiness, that is, the higher the real earnings management level is, the lower the cost stickiness is, which verifies hypothesis $1 \mathrm{~b}$.

Table 4: The Multivariate Regression Results of Model 1

\begin{tabular}{|c|c|c|c|}
\hline Variables & $\begin{array}{l}\text { Regression } \\
\text { Coefficient }\end{array}$ & $\mathrm{t}$ & Significance \\
\hline Constant & 0.486 & 1.327 & 0.186 \\
\hline $\mathrm{REM}_{\mathrm{t}}$ & -0.057 & -3.348 & 0.001 \\
\hline$(\Delta \mathrm{LnREV})_{\mathrm{t}}$ & 0.190 & 2.580 & 0.011 \\
\hline DEC & -0.038 & -0.739 & 0.461 \\
\hline SIZE & -0.026 & -1.576 & 0.117 \\
\hline $\mathrm{AI}$ & 0.002 & -0.412 & 0.681 \\
\hline EI & 0.084 & 0.478 & 0.633 \\
\hline & \multicolumn{2}{|c|}{$\mathrm{R}^{2}$} & 0.183 \\
\hline & \multicolumn{2}{|c|}{ Adj-R ${ }^{2}$} & 0.155 \\
\hline & \multicolumn{2}{|c|}{$\mathrm{F}=6.399$} & Sig. $=0.000$ \\
\hline
\end{tabular}

\subsubsection{The impact of executive compensation on cost stickiness}

Table 5: The Multivariate Regression Results of Model 2

\begin{tabular}{|c|c|c|c|}
\hline Variables & $\begin{array}{l}\text { Regression } \\
\text { Coefficient }\end{array}$ & $\mathrm{t}$ & Significance \\
\hline Constant & 0.137 & 0.378 & 0.706 \\
\hline$(\Delta \mathrm{LnREV})_{\mathrm{t}}$ & 0.249 & 3.337 & 0.001 \\
\hline PAY & -0.010 & 0.300 & 0.765 \\
\hline DEC & -0.025 & -0.483 & 0.630 \\
\hline SIZE & -0.012 & -0.668 & 0.505 \\
\hline $\mathrm{AI}$ & $5.750 \mathrm{E}-5$ & 0.010 & 0.992 \\
\hline EI & 0.110 & 0.605 & 0.546 \\
\hline & \multicolumn{2}{|c|}{$\mathrm{R}^{2}$} & 0.130 \\
\hline & \multicolumn{2}{|c|}{ Adj- $R^{2}$} & 0.100 \\
\hline & \multicolumn{2}{|c|}{$\mathrm{F}=4.269$} & Sig. $=0.000$ \\
\hline
\end{tabular}

Table 5 shows the regression analysis results of Model 2. As can be seen from the results, the adjusted $\mathrm{R}^{2}$ in the regression model is 0.100 , which is significant at the $1 \%$ level, indicating that the model has a good goodness of fit. The regression coefficient between the executive compensation level and cost stickiness is negative, indicating that the executive compensation level is negatively correlated with cost stickiness, that is, the higher the executive compensation level, the lower the degree of cost stickiness, which verifies hypothesis 2 .

4.3.3 The relationship between executive compensation and the company's real earnings management level.

Table 6 shows the regression analysis results of Model 3. As can be seen from the results, the adjusted $\mathrm{R}^{2}$ in the regression model is 0.125 , which is significant at the $1 \%$ level, indicating a good fitting degree of the model. It can be seen from the regression results that the regression coefficient between the executive compensation level and the real earnings management level is positive, indicating that the executive compensation of listed companies is positively correlated with the real earnings management level, that is, the higher the executive compensation level is, the higher the real earnings management level is, which verifies hypothesis $3 \mathrm{a}$.

Table 6: The Multivariate Regression Results of Model 3

\begin{tabular}{|c|c|c|c|}
\hline Variables & $\begin{array}{l}\text { Regression } \\
\text { Coefficient }\end{array}$ & $\mathrm{t}$ & Significance \\
\hline Constant & 6.372 & 4.082 & 0.000 \\
\hline PAY & 0.394 & 2.757 & 0.006 \\
\hline SIZE & -0.389 & -4.902 & 0.000 \\
\hline $\mathrm{DEC}_{\mathrm{t}-1}$ & 0.142 & 0.688 & 0.492 \\
\hline $\mathrm{AI}$ & 0.043 & 1.654 & 0.100 \\
\hline EI & -0.428 & -0.529 & 0.597 \\
\hline & \multicolumn{2}{|c|}{$\mathrm{R}^{2}$} & 0.150 \\
\hline & \multicolumn{2}{|c|}{ Adj-R ${ }^{2}$} & 0.125 \\
\hline & \multicolumn{2}{|c|}{$F=6.064$} & Sig. $=0.000$ \\
\hline
\end{tabular}

4.3.4 The relationship among executive compensation, real earnings management and fee stickiness.

Table 7 shows the regression analysis results of Model 4. It can be seen from the results that adj- $\mathrm{R}^{2}$ in the regression model is 0.190 , indicating that the goodness of fit of the model has been improved. When the variable of executive compensation is added, the correlation coefficient between real earnings management level and expense stickiness changes from -0.282 to -0.065 , indicating that the negative correlation between earnings management level and expense stickiness weakens under the influence of executive compensation. The empirical results support hypothesis 4 proposed above. 
Table 7: The Multivariate Regression Results of Model 4

\begin{tabular}{|c|c|c|c|}
\hline Variables & $\begin{array}{l}\text { Regression } \\
\text { Coefficient }\end{array}$ & $\mathrm{t}$ & Significance \\
\hline Constant & 0.540 & 1.541 & 0.125 \\
\hline $\mathrm{REM}_{\mathrm{t}}$ & -0.065 & -3.787 & 0.000 \\
\hline$(\Delta \mathrm{LnREV})_{\mathrm{t}}$ & 0.137 & 2.210 & 0.028 \\
\hline PAY & 0.030 & 0.950 & 0.343 \\
\hline SIZE & -0.035 & -1.915 & 0.057 \\
\hline $\mathrm{DEC}_{\mathrm{t}-1}$ & -0.137 & -2.775 & 0.006 \\
\hline AI & 0.003 & 0.447 & 0.656 \\
\hline EI & 0.117 & 0.674 & 0.501 \\
\hline & \multicolumn{2}{|c|}{$\mathrm{R}^{2}$} & 0.222 \\
\hline & \multicolumn{2}{|c|}{ Adj-R ${ }^{2}$} & 0.190 \\
\hline & \multicolumn{2}{|c|}{$\mathrm{F}=6.923$} & Sig. $=0.000$ \\
\hline
\end{tabular}

\subsection{Robustness Test}

To ensure the credibility of the research results, this paper will on behalf of the company on behalf of the company may cost stickiness level with the same viscosity level of operating cost and rate of change of the sum of the cost of pin tube instead of robustness inspection again for four hypotheses proposed in this paper, regression analysis, found that the empirical results are consistent with the above research results.

\section{Conclusions and Suggestions}

\subsection{Conclusions}

This paper collected relevant data of China's listed manufacturing companies from 2018 to 2020, and explored the correlation between executive compensation level, real earnings management behavior and expense stickiness. The main conclusions are as follows:

(1) The real earnings management behavior of Chinese manufacturing enterprises is negatively correlated with cost stickiness, that is, the degree of cost stickiness will decrease with the improvement of real earnings management.

(2) The executive compensation level of Chinese manufacturing enterprises is negatively correlated with cost stickiness, that is, the degree of cost stickiness will decrease with the increase of the executive compensation level of real enterprises.

(3) There is a significant positive correlation between the executive compensation level of China's manufacturing enterprises and the degree of real earnings management, that is, the existence of the management compensation incentive system negatively hinders the internal management of enterprises, and executives will take real earnings management behavior to maximize their own interests.

(4) Executive compensation level will weaken the negative correlation between real earnings management and expense stickiness, that is, the negative correlation between real earnings management level and expense stickiness will weaken with the increase of executive compensation level.

\subsection{Suggestions}

Based on the above research, this paper puts forward the following suggestions: (1) establish a perfect cost and expense management responsibility system, further refine the cost and expense management responsibility, in order to reduce the stickiness of cost and improve the efficiency of cost management. (2) Establish a reasonable and effective compensation system and incentive system, moderately increase the level of executive compensation, pay attention to the fairness of executive internal compensation mechanism, motivate managers to maximize corporate value, improve management efficiency, and curb managers' real earnings management behavior. (3) Strengthen enterprise internal control and internal audit, through strict rules and regulations, effective internal communication and targeted incentive mechanism for managers to supervise, improve the quality of internal control, and have direct and indirect supervision and balance on managers' decision-making behavior.

\section{References}

[1] Lu Jianqiao. Researches on accounting and auditing in the post-Enron era[J]. Accounting Research, 2002(1): 33-42.

[2] Fu Qi, Deng Chuan. Managerial power, executive compensation and earnings management under complete circulation $[\mathrm{J}]$. Collected Essays on Finance and Economics, 2013(4): 66-72.

[3] Wang Fusheng, Ji Shanshan, Cheng Fu. The effect of earnings management on future operating performance: a comparative study between accrual earnings management and real earnings management[J]. Nankai Business Review, 2014, 17(2): 95-106.

[4] Yang Zhiqiang, Wang Hua. Internal pay dispersion, ownership concentration and earnings managementbasing on the salaries comparative analysis[J]. Accounting Research, 2014(6): 57-65.

[5] Liang Shangkun. Will the incentive intensity of equity compensation affect enterprise's cost stickiness[J]. Journal of World Economy, 2013(1): 144-155.

[6] Li Zhengguang, Dai Wei, Xu Kai, Zhang Shigen. Earnings management, corporate governance and cost stickiness[J]. Finance and Accounting, 2017(9): 16-21.

[7] Meng liyuan, He Weijia. Real earnings management, internal control and cost stickiness[J]. Communication of Finance and Accounting, 2019(21): 115-119.

[8] Jensen, M. C. and Meckling, W. H. Theory of the firm: Managerial behavior, agency costs and ownership structure[J]. Journal of Financial Economics, 1976, 3(4): 305-306.

[9] Kanniainen, V. Empire building by corporate managers: The corporation as a savings instrument[J]. Journal of Dynamics and Control, 2000, 24(1): 127-142.

[10] Dong Liping, Zhuang Jun. The relationship between managerial performance-related pay and earnings management under the perspective of majority shareholder's governance $[\mathrm{J}]$. China Business and Market, 2018(12):73-86.

[11] Gul F A, Chen C J P, Tsui J S L. Discretionary accounting accruals, managers' incentives, and audit fees[J]. Contemporary Accounting Research, 2003, 20(3): 441-464.

[12] Cheng Q, Warfield T D. Equity incentives and earnings management[J]. Accounting Review, 2005, 80(2): 441-476. 
[13] Philippon T, Bergstresser D B. CEO incentives and earnings management[J]. Journal of Financial Economics, 2006, 80(3): 511-529.

[14] Efendi J, Srivastava A, Swanson E P. Why do corporate managers misstate financial statement? The role of option compensation and other factors[J]. Journal of Financial Economics, 2007, 85(3): 667-708.

[15] Cornett M M, Mcnutt J J, Tehranian H. Corporate governance and earnings management at large U.S. bank holding companies[J]. Journal of Corporate Finance, 2009, 15(4): 412-430.

[16] Wang Kemin, Wang Zhichao. Executive control, remuneration and earnings management-based on the empirical research of Chinese listed companies[J]. Management World, 2007(7), 111-119.

[17] Sugata, Roychowdhury. Earnings management through real activities manipulation[J]. Journal of Accounting and Economics, 2006, 335-370. 